\title{
Estimating evapotranspiration using remote sensing and the Surface Energy Balance System - A South African perspective
}

\author{
LA Gibson*1,4 , C Jarmain ${ }^{2}, \mathrm{Z} \mathrm{Su}^{3}$ and FE Eckardt ${ }^{4}$ \\ ${ }^{1}$ Agricultural Research Council-Institute for Soil, Climate and Water, Private Bag X5017, Stellenbosch, 7599, South Africa \\ 2University of KwaZulu-Natal, Private Bag X01, Scottsville, 3201, South Africa \\ ${ }^{3}$ University of Twente, Faculty of Geo-Information Science and Earth Observation (ITC), Hengelosestraat 99, PO Box 217, 7500 AE Enschede, \\ The Netherlands \\ ${ }^{4}$ University of Cape Town, Department of Environmental and Geographical Science, South Lane, Upper Campus, Private Bag X3, \\ Rondebosch, 7701, South Africa
}

\begin{abstract}
Remote sensing-based evapotranspiration (ET) algorithms developed in recent years are well suited for estimating evapotranspiration and its spatial trends over time. In this paper the application of energy balance methods in South Africa is reviewed, showing that the Surface Energy Balance Algorithm for Land (SEBAL) model is the most widely used, but highlighting the potentials of the Surface Energy Balance System (SEBS) model. The SEBS model is then reviewed in the international literature and lessons learned from South African examples are expanded upon. The SEBS model has been extensively used for teaching and training purposes and has been applied in research projects across many different environments. However, there are discrepancies in the reported accuracy of the SEBS model due to known model sensitivities. It is therefore recommended that any further research using the SEBS model in South Africa should be limited to agricultural areas where accurate vegetation parameters can be obtained, where high resolution imagery with low sensor zenith angles is available, and where canopy cover is complete.
\end{abstract}

Keywords: Evapotranspiration, remote sensing SEBS, SEBAL

\section{INTRODUCTION}

Accurate estimates of temporal and spatial variations in precipitation and evapotranspiration (ET) are critical for improved understanding of the interactions between land surfaces and the atmosphere (Mu et al., 2007). Methods for monitoring the water balance at both local and regional scales are required to preserve and manage water resources (Melesse et al., 2006), particularly in light of increasing human consumption, climate impacts and the consequent decreasing availability of water resources. However, the water cycle is difficult to quantify accurately because of the heterogeneity of the landscape and the large number of controlling factors involved, including climate, plant biophysics, soil properties, and topography $(\mathrm{Mu}$ et al., 2007). In a water-scarce country like South Africa, with a number of large consumers of water, it is important to estimate ET with a high degree of accuracy. This is especially important in the semi-arid regions where there is an increasing demand for water and a scarce supply thereof. ET varies regionally and seasonally, so knowledge on evaporation is fundamental to save and secure water for different uses, and to guarantee that water is distributed to water consumers in a sustainable manner.

Numerous remote sensing-based ET algorithms, varying in complexity, have been developed;Verstraeten et al. (2008)

\footnotetext{
* To whom all correspondence should be addressed.

Current affiliation: GEOSS, Unit 19, Technostell, 9 Quantum Street,

Technopark, Stellenbosch, 7600.

푤 +27 21 880-1079; e-mail: lgibson@geoss.co.za

Received 5 March 2012; accepted in revised form 8 July 2013.
}

provide a review and classify the different methods into 4 broad classes based on the: (i) parameterisation of the energy balance, (ii) Penman-Monteith formulation, (iii) water balance and (iv) vegetation index/land surface temperature relationships. Remote sensing-based ET algorithms developed in recent years fill an existing gap: they are well suited for estimating crop water use or ET (Allen et al., 2007) and the spatial trends thereof over time. Remote sensing technology holds great promise (Jha and Chowdary, 2006) as it can cost-effectively provide frequent data on a relatively large scale that allow specific water resource situations to be monitored on a longterm basis.

In this paper the application of energy balance methods for estimating ET in South Africa is reviewed. It will be shown that the Surface Energy Balance Algorithm for Land (SEBAL) model is the most widely applied model in South Africa. However, it is protected by intellectual property law and is not available for unaffiliated researchers to use. Conversely, the Surface Energy Balance System (SEBS) is an open-source model widely used for teaching and training purposes. Therefore the second half of the paper will be a review of local and international applications of SEBS, highlighting its strengths, weaknesses and sensitivities; some recommendations on its future use in South Africa will be made.

\section{Estimating evapotranspiration using energy balance methods in South Africa}

A number of conventional methods exist to estimate ET at field scale. These methods, such as the Bowen ratio, eddy covariance, 


\begin{tabular}{|c|c|c|c|c|c|}
\hline \multicolumn{6}{|c|}{$\begin{array}{c}\text { TABLE } 1 \\
\text { Summary of studies conducted in South Africa. Different methods for estimating ET were assessed } \\
\text { and their usefulness in various water resources applications and across various spatial and } \\
\text { temporal scales were assessed in historical and operational mode }\end{array}$} \\
\hline Type & Study focus & Parameters & Temporal scale & $\begin{array}{l}\text { Spatial scale / } \\
\text { resolution }\end{array}$ & Reference \\
\hline Review & Methodology & ET, energy balance & $\begin{array}{l}\text { Instantaneous, day, } \\
\text { week, month }\end{array}$ & Field / $30 \mathrm{~m}$ & Jarmain et al. (2009) \\
\hline Historic & Catchment water use & $\begin{array}{l}\text { ET, rain, run- } \\
\text { off, groundwater } \\
\text { recharge }\end{array}$ & $\begin{array}{l}\text { Day, month, year for } \\
1 \text { year }\end{array}$ & Catchment / $1 \mathrm{~km}$ & Gibson et al. (2009) \\
\hline Historic & $\begin{array}{l}\text { Catchment water use } \\
\text { efficiency }\end{array}$ & ET & $\begin{array}{l}\text { Day, 2-weekly for } 3 \\
\text { years }\end{array}$ & $\begin{array}{l}\text { Field, catchment / } \\
250 \mathrm{~m}\end{array}$ & Hellegers et al. (2011) \\
\hline Historic & $\begin{array}{l}\text { Natural veld water } \\
\text { use }\end{array}$ & ET & Day, season, annual & Regional / 1 km & $\begin{array}{l}\text { Palmer and } \\
\text { Weideman }(2011)^{* *}\end{array}$ \\
\hline Historic & $\begin{array}{l}\text { IAP, natural veld } \\
\text { water use }\end{array}$ & ET, rain, rain-ET & $\begin{array}{l}\text { Day, two-weekly for } \\
3 \text { years }\end{array}$ & Provincial / $250 \mathrm{~m}$ & $\begin{array}{l}\text { Jarmain and } \\
\text { Meijninger (2012) }\end{array}$ \\
\hline Historic & Catchment hydrology & ET, energy balance & 90 days & Catchment / $250 \mathrm{~m}$ & $\begin{array}{l}\text { Kongo and Jewitt } \\
(2006)\end{array}$ \\
\hline Historic & $\begin{array}{l}\text { Agricultural water } \\
\text { use efficiency }\end{array}$ & ET & 3 years & Field, regional / $30 \mathrm{~m}$ & Klaasse et al. (2008) \\
\hline Operational & $\begin{array}{l}\text { Agricultural water } \\
\text { use efficiency }\end{array}$ & $\begin{array}{l}\text { ET, soil moisture, } \\
\text { energy balance }\end{array}$ & $\begin{array}{l}\text { Weekly, } 8 \text { months } \\
\text { (grape growing } \\
\text { season) }\end{array}$ & Field, regional / $30 \mathrm{~m}$ & $\begin{array}{l}\text { Klaasse et al. (2011); } \\
\text { Jarmain et al. (2011a) }\end{array}$ \\
\hline Operational & $\begin{array}{l}\text { Agricultural water } \\
\text { use efficiency }\end{array}$ & ET, energy balance & $\begin{array}{l}\text { Weekly, for a period } \\
\text { of } 12 \text { months }\end{array}$ & $\begin{array}{l}\text { Field, farm, region / } \\
30 \mathrm{~m}\end{array}$ & Jarmain et al. (2011b) \\
\hline Operational & $\begin{array}{l}\text { Agricultural water } \\
\text { management }\end{array}$ & $\begin{array}{l}\text { ET, soil moisture, } \\
\text { energy balance }\end{array}$ & $\begin{array}{l}\text { Weekly, } 8 \text { months } \\
\text { (grape growing } \\
\text { season) }\end{array}$ & Field, regional / $30 \mathrm{~m}$ & $\begin{array}{l}\text { Jarmain and Klaasse } \\
\text { (2012) }\end{array}$ \\
\hline Operational & $\begin{array}{l}\text { Catchment scale } \\
\text { planning and water } \\
\text { allocation }\end{array}$ & ET, rain, rain-ET & $\begin{array}{l}\text { Weekly for a period } \\
\text { of } 12 \text { months }\end{array}$ & $\begin{array}{l}\text { Field, catchment, } \\
\text { region / } 30 \mathrm{~m}\end{array}$ & WE Consult (2011) \\
\hline
\end{tabular}

"This study did not apply the energy balance approach for estimating ET.

surface renewal, scintillometry and lysimeter systems have been reviewed and extensively applied in South Africa (Savage et al., 2004; Jarmain et al., 2009). However, with the exception of scintillometry, they do not integrate spatial trends in ET. In the past, field-scale ET estimates obtained from these methods were fed into models operating at a catchment scale or used to validate results from models operating at large scales. Most of these catchment-scale models that estimate ET use point data and not spatial data, but some involve methods to disaggregate point data for spatial representation.

In recent years, a number of studies conducted in South Africa reviewed and applied remote sensing-based methods for improved water resources management (Table 1). The evolution of the research from a review of methods, to the historic estimation of ET, through to the operational use of these methods using near real-time data, is evident in Table 1. In the first review, Jarmain et al. (2009) evaluated various models that estimate evaporation spatially using earth observation data, and reported that SEBAL, Mapping Evapotranspiration with High Resolution and Internalised Calibration (METRIC) and SEBS quite easily simulated net radiation accurately, but the accuracy of soil heat flux and heat storage of a water body was more variable. Similarly, for the sensible heat flux density $(H)$ at the time of satellite overpass for various land uses and with different models, accurate estimates of simulated $H$ were not always achieved. Evaporative fraction $(E F)$ estimates were simulated accurately in many cases. The Vegetation Index / Temperature
Trapezoid (VITT) model generally yielded the least accurate evaporation estimates of the land uses studied.

The differing spatial scales at which remote-sensing estimation of ET has been carried out in South Africa, from field scale through to catchment and regional scale, are categorised (Table 1). Further to the review by Jarmain et al. (2009), field-scale studies assessing the application of remote-sensing data to water use efficiency have been carried out using the SEBAL model with high resolution (predominantly Landsat) imagery (Klaasse et al., 2008; Klaasse et al., 2011; Jarmain et al., 2011a; Jarmain et al., 2011b; Hellegers et al., 2011; Jarmain and Klaasse, 2012; WE Consult, 2011). A benefit of conducting field-scale studies is that in situ validation, although expensive, is achievable and was indeed achieved for a number of the aforementioned projects.

Various remote-sensing data applications at catchment scale (Table 1) have been investigated for catchment hydrology (Kongo and Jewitt, 2006), water use estimation (Gibson et al., 2009; Hellegers et al., 2011) and, most recently, operational water planning and allocation purposes (WE Consult, 2012). Kongo and Jewitt (2006) were the first to investigate the use of remote-sensing data to estimate ET in South Africa at catchment level, investigating a catchment's response to rainwater harvesting. Gibson et al. (2009) used the SEBS model to calculate annual ET for a quaternary catchment in the Western Cape, to assess the compliance of water users to water use legislation. The results of the study were inconclusive as the estimated 
annual catchment ET significantly exceeded the estimated annual catchment rainfall. Finally, Hellegers et al. (2011) used SEBAL estimates of ET to assist in assessing competing claims on water resources in the transboundary Inkomati catchment shared between South Africa, Swaziland and Mozambique.

At a provincial scale, Jarmain and Meijninger (2012), using SEBAL, assessed the impact of invasive alien plant species (IAPs), and the clearing thereof by the Working for Water (WfW) programme, on ET and the availability of water resources in the Western Cape and KwaZulu-Natal provinces. They concluded that this approach (combining spatial ET data with information on land use) can be used to determine the ET of IAPs. Although the $250 \mathrm{~m}$ resolution SEBAL data can be used, higher resolution data $(<30 \mathrm{~m})$ would better assess the impact of IAPs on ET across a wider range of invasion densities and water regimes, including riparian zones. Suited to regional ET estimation but differing from the energy balance methods, a parsimonious spatial ET method based on leaf area index (LAI) and the Penman-Monteith equation (Palmer and Weideman, 2011) has been used with good success in several areas in South Africa. This method uses the MODIS LAI to convert reference evapotranspiration $\left(\mathrm{ET}_{0}\right.$ ) from the Penman-Monteith equation to actual ET for each pixel. This method has been found to be particularly suited to natural vegetation with specific application to determining the water use efficiency (WUE) of rangelands.

The methods having proved their usefulness in historic studies have evolved into operational applications in a number of instances (Table 1). Two SEBAL studies (Klaasse et al., 2008) using high resolution Landsat imagery determined the ET, biomass production and biomass WUE of table and wine grapes in the main production areas of the Western Cape for 3 grape seasons. The interest generated by this study led to the initiation of an operational project where remote sensingbased data maps and other information were made available at a weekly time-step via a GrapeLook website (Klaasse et al., 2011) for table and wine grape producing areas of the Western Cape. Grapelook was the first African example where ET and related data maps (biomass, WUE, nitrogen content), as well as satellite data-derived irrigation advice, were determined and made available to users. This approach was subsequently extended to include deciduous fruit producing areas of the Western Cape (Jarmain and Klaasse, 2012) for the growing season of 2011-12. This operational approach is being replicated in 2 studies to assess the WUE of sugarcane and grain crops. Weekly data maps are disseminated through the website viewers SugarcaneLook (Jarmain et al., 2011b) and GrainLook (Jarmain et al., 2013). Following on from the study conducted in the Inkomati catchment (Hellegers et al., 2011), the European Union-funded project WATPLAN was launched. WATPLAN aims to develop a web-based, operational tool (www.watplan. com) where water balance information (rainfall, ET, Rain-ET) for the entire Inkomati catchment is disseminated weekly. Information provided through WATPLAN will be integrated with the operational water resources management system of the Inkomati Catchment Management Agency (CMA).

Arising from past and current operational projects has been the realisation that field validation of remotely-sensed ET estimates is a necessary component of these operations to allow for data products to be used with confidence. Further, the need to find further users of and uses for the data products has become apparent. The presentation of the end product and its usability differs from historic studies where a map may be an acceptable deliverable. For operational applications of remote-sensed
ET estimates to be adopted, there is a need to integrate the ET data products into other systems such as irrigation scheduling, allowing for ease of use and interpretation.

Finally, it should also be mentioned that a number of freely downloadable ET data products exist, for example the Landsaf (EUMETSAT; www.eaumetsat.int) data and MODIS 16 ET product. Jarmain et al. (2009) refer to a number of others. The MOD16 ET product, specifically, has generated interest. The MODIS Science Team, in 2011, released a MODIS ET data product (MOD16) available freely for download. The MOD16 ET products are regular 1- $\mathrm{km}^{2}$ global land surface ET datasets for vegetated land areas at 8-day and monthly intervals (Mu et al., 2011). The MOD16 ET product is created using MODIS global landcover (MOD12Q1), a daily meteorological reanalysis dataset from NASA's Global Modelling and Assimilation Office, and MODIS biophysical parameters (albedo, leaf area index, and enhanced vegetation index) as input into the Penman-Monteith equation. The algorithm performance has been validated against 46 flux tower measurements across 7 biomes but validation in Africa has not been published to date.

\section{The SEBS model}

The energy balance approach holds great promise for application in South Africa. The SEBS model, one of the energy balance approaches, was developed by $\operatorname{Prof} \mathrm{Z} \mathrm{Su}$, at the ITC in The Netherlands; the formulation publication (Su, 2002) describes the model and provides the required equations. The SEBS model has been extensively used for teaching and training purposes at the ITC and as such it has been widely applied across many different countries; however, it is not yet used in operational applications. SEBS is available as a pre-packaged tool in various software packages, originally coded in IDL language, and implemented in BEAM with Java and in ILWIS with C++. As with other energy balance approach models, the SEBS model estimates daily actual ET from remotely-sensed and meteorological data by calculating the energy required for water to change phase from liquid to gas:

$$
\lambda E=R_{n}-G_{0}-H
$$

where:

$$
\begin{aligned}
& \lambda E \text { is the turbulent latent heat flux ( } \lambda \text { is the latent heat of } \\
& \text { vaporisation and } E \text { is water vapour flux density), } \\
& R_{n} \text { is net radiation } \\
& G_{0} \text { is the soil heat flux and } \\
& H \text { is the sensible heat flux ( } \mathrm{Su}, 2002)
\end{aligned}
$$

The latent heat flux is calculated indirectly as a residual after the sensible heat flux has been derived. Therefore there is an associated uncertainty in the derived latent heat flux. In SEBS this uncertainty is considered to be limited by determining the energy balance at the limiting cases, since the actual sensible heat flux is constrained to the range set by the sensible heat flux at the wet limit (derived from a combination equation), and the sensible heat flux at the dry limit (set by the available energy). The relative evaporation is inferred from the sensible heat flux and the sensible heat flux calculated at the wet and dry limits. The relative evaporation is, in turn, used together with $R_{n}, G_{0}$ and the latent heat flux at the wet limit to derive the evaporative fraction (Eqs. (2) and (3)).

$$
\Lambda_{r}=1-\frac{H-H_{w e t}}{H_{d r y}-H_{w e t}}
$$


where:

$\Lambda_{r}$ is relative evaporation,

$H$ is the sensible heat flux and

$H_{w e t}$ and $H_{d r y}$ are the sensible heat flux at the wet and dry

limits, respectively.

$$
\Lambda=\frac{\lambda E}{R_{n}-G_{0}}=\frac{\Lambda_{r} \cdot \lambda E_{\text {wet }}}{R_{n}-G_{0}}
$$

where:

$\Lambda$ is the evaporative fraction

$\lambda E$ and $\lambda E_{\text {wet }}$ are the latent heat flux and the latent heat flux at the wet limit, respectively

In SEBS it is assumed that the daily value of evaporative fraction is approximately equal to the instantaneous value, and, from this, the daily evaporation can be determined as:

$$
E T=8.64 \times 10^{7} \times \frac{\Lambda \cdot \overline{R_{n}}}{\lambda \rho_{w}}
$$

where:

$E T$ is the actual evaporation on daily basis $\left(\mathrm{mm} \cdot \mathrm{d}^{-1}\right)$

$\lambda$ is the latent heat of vaporization $\left(\mathrm{J} \cdot \mathrm{kg}^{-1}\right)$

$\rho_{w}$ is the density of water $\left(\mathrm{kg} \cdot \mathrm{m}^{-3}\right)$

$R_{n}^{w}$ is the daily net radiation flux (Lin et al., 2008)

$8.64 \times 10^{7}$ is the constant used to convert instant ET to daily

(24 h) ET

Since its formulation 10 years ago, the SEBS model has been widely published (Table 2). The environment in which the SEBS model has been most extensively applied is agriculture ( $\mathrm{Su}, 2002$; Jia et al., 2003; Su et al., 2005; Timmermans et al., 2005; Hailegiorgis, 2006; Lin, 2006; McCabe and Wood, 2006). However, there are variations from sparsely vegetated and barren land (Xin, 2007), forests (Badola, 2009), wetlands (Alvarez, 2007), and, most recently, urban areas and grasslands (Rwasoka et al., 2011).

It is difficult to properly assess the accuracy of the results from the SEBS model from the literature as there is no standard method for presenting the results, and validation methods and their associated accuracies vary from study to study. However, published results of the SEBS model have been validated with a variety of field and/or complementary methodologies such as the lysimeter (Lin, 2006), eddy covariance or Bowen ratio methods (Su, 2002; Su et al., 2005; Timmermans et al., 2005; McCabe and Wood, 2006; Badola, 2009; Van der Kwast et al., 2009), and the large aperture scintillometer (Jia et al., 2003; Timmermans et al., 2005). Additionally, results have been compared to hydro-meteorological equations (Hailegiorgis, 2006; Lin, 2006; Gebreyesus, 2009) and the water balance or by examining hydrological consistency with other datasets (Su and Roerink, 2004; Alvarez, 2007; McCabe et al., 2008; Pan et al., 2008).

The accuracies in the evapotranspiration and energy flux estimates as determined using the SEBS model are comparable with validation measurements as shown by Alvarez (2007), Gebreyesus (2009), Hailegiorgis (2006), Jia et al. (2003), Lin (2006), McCabe and Wood (2006), McCabe et al. (2008), Su (2002), Su et al. (2005), Timmermans et al. (2005) and Van der Kwast et al. (2009). For the most part, the model is reported to be returning realistic results; however, overestimation of the latent heat flux (McCabe and Wood, 2006), extreme overestimation of the latent heat flux in a forested area (Badola, 2009) and overestimation of daily ET at a grassland site (Rwasoka et al., 2011) have also been reported. Since the SEBS model was originally developed for agriculture the inference may be that some model parameterisation is not suitable for non-agricultural landcovers. This is particularly true for the parameterisation of roughness length for heat transfer due to the inherently less uniform nature of natural vegetation.

Additional inaccuracies have been ascribed to more than one landcover being present in one pixel (Van der Kwast et al., 2009) and landscape heterogeneity (Rwasoka et al., 2011). Furthermore, several authors have highlighted the parameters to which the SEBS model is most sensitive. These proposed parameters are extensive and include: roughness length (Lin, 2006; Alvarez, 2007; Van der Kwast et al., 2009; Gebreyesus, 2009; Rwasoka et al., 2011), displacement height (Lin, 2006), land surface temperature (Badola, 2009; Van der Kwast et al., 2009; Rwasoka et al., 2011), wind speed and wind direction (Van der Kwast et al., 2009), fractional vegetation cover (Badola, 2009; Lin, 2006), surface emissivity (Badola, 2009; Van der Kwast et al., 2009; Lin, 2006), albedo (Badola, 2009; Van der Kwast et al., 2009), normalised difference vegetation index (NDVI) (Badola, 2009; Van der Kwast et al., 2009), shortwave incoming radiation (Van der Kwast et al., 2009) and the height of the planetary boundary layer (Van der Kwast et al., 2009). It is therefore clear that, due to the complex nature of the SEBS model and the multiple input parameters from remote sensing and meteorological measurements, there are many potential sources of error, and the sensitivity of the model may not be to only one parameter in isolation but to parameters in combination, particularly when used over landcovers for which the model was not specifically designed. However, in agricultural environments, evapotranspiration estimated from the SEBS model is generally reported to be in agreement with validated measurements.

Taking a catchment scale approach, coarse resolution MODIS TERRA and AQUA data has been used by Gibson et al. (2009), Gibson et al. (2011a) and Gibson et al. (2011b). Gibson et al. (2011a) reported an underestimation of the sensible heat flux when compared with measurements from an eddy covariance system (Jarmain and Mengistu, 2011), and put forward 4 points of advice when using the SEBS model pre-packaged in ILWIS. These pertained to: (i) the uncertainties associated with land surface temperature retrievals and the sensitivity of SEBS to this parameter; (ii) the choice of fractional vegetation cover formula; (iii) the choice of weather station relating to the height at which wind speed is measured; and (iv) landscape heterogeneity and pixel resolution. Gibson et al. (2011b), acting on these points of advice, reported that the SEBS model was sensitive to roughness length, particularly in combination with land surface temperature; however, despite applying different methods of estimating roughness length, no significant changes in the calculation of the sensible heat flux were found.

Jarmain et al. (2009) used high-resolution satellite data (Landsat ETM) to retrieve the remote sensing biophysical parameters required by the SEBS model, and evaluated outputs in a variety of environments, including an open water surface, forestry plantation, wetlands and native vegetation under semiarid environments with varying vegetative cover. Jarmain et al. (2009) reported that SEBS quite easily simulated net radiation accurately, but the accuracy of soil heat flux was more variable. Similarly, for the sensible heat flux density $(H)$ at the time of satellite overpass for various land uses and with different models, accurate estimates of simulated $H$ were not always achieved. Evaporative fraction (EF) estimates were simulated accurately in many cases.

The complexity of the SEBS model and therefore the potential for the introduction of many errors; the coarse spatial 


\begin{tabular}{|c|c|c|c|c|}
\hline \multicolumn{5}{|c|}{$\begin{array}{l}\text { TABLE } 2 \\
\text { Remote sensing estimation of ET using SEBS: chronological summary of SEBS publications, } \\
\text { with scales and reported accuracies }\end{array}$} \\
\hline Spatial scale / sensor & Study area & Environments & Reported accuracies & Reference \\
\hline $\begin{array}{l}\text { Field / } \\
\text { TMS-NS001 }\end{array}$ & Barrax, Spain & Shrub, cotton, grass & $\begin{array}{l}\text { Mean error of SEBS is estimated to be } \\
\text { around } 20 \% \text { relative to the mean sensible } \\
\text { heat flux. }\end{array}$ & $\mathrm{Su}(2002)$ \\
\hline $\begin{array}{l}\text { Local: across } \\
2-61000 \mathrm{~m} \\
\text { resolution pixels / } \\
\text { ATSR }\end{array}$ & $\begin{array}{l}\text { Three locations in } \\
\text { Spain }\end{array}$ & $\begin{array}{l}\text { Dry vineyard surface, } \\
\text { irrigated fruit trees and } \\
\text { alfalfa, various irrigated } \\
\text { crops }\end{array}$ & $\begin{array}{l}\text { RMSD for dry vineyard }=24.2 \mathrm{~W} \cdot \mathrm{m}^{-2} \\
\text { Irrigated fruit trees and alfalfa } \\
=36.5 \mathrm{~W} \cdot \mathrm{m}^{-2} \\
\text { Mixed irrigated crops }=8.5 \mathrm{~W} \cdot \mathrm{m}^{-2}\end{array}$ & Jia et al. (2003) \\
\hline $\begin{array}{l}\text { Field and regional } \\
\text { / Landsat, GOESS, } \\
\text { MODIS }\end{array}$ & Iowa, USA & Corn and soybeans & $\begin{array}{l}\text { Five corn sites: relative root-mean-square } \\
\text { error }=13.32 \% \text {; root mean absolute error } \\
=9.73 \% \\
\text { Three soybean sites root-mean-square } \\
\text { error }=14.02 \% \text {; root mean absolute error } \\
=10.72 \%\end{array}$ & Su et al. (2005) \\
\hline Field / ASTER & Barrax, Spain & $\begin{array}{l}\text { Forest nursery, wheat } \\
\text { stubble, vineyard, sun- } \\
\text { flower, corn }\end{array}$ & $\begin{array}{l}\text { Slight underestimation of } R_{n}, G_{0} \text { slightly } \\
\text { underestimated for low vegetation cover, } \\
\text { underestimated } H \text { of up to } 140 \mathrm{~W} \cdot \mathrm{m}^{-2}\end{array}$ & $\begin{array}{l}\text { Timmermans et } \\
\text { al. (2005) }\end{array}$ \\
\hline $\begin{array}{l}\text { Regional: catch- } \\
\text { ment / Landsat }\end{array}$ & $\begin{array}{l}\text { Regge and Dinkel, } \\
\text { The Netherlands }\end{array}$ & $\begin{array}{l}\text { Heath lands, grasses, } \\
\text { forests and crops } \\
\text { (maize) }\end{array}$ & $\begin{array}{l}\text { ET reported to be satisfactory when com- } \\
\text { pared with } E T_{0}\end{array}$ & $\begin{array}{l}\text { Hailegiorgis } \\
(2006)\end{array}$ \\
\hline Regional / MODIS & $\begin{array}{l}\text { Hebei Plain, } \\
\text { Northeastern } \\
\text { China }\end{array}$ & $\begin{array}{l}\text { Predominantly } \\
\text { croplands }\end{array}$ & $\begin{array}{l}\text { Good agreement reported between SEBS } \\
\text { ET and lysimeter values }\end{array}$ & Lin (2006) \\
\hline $\begin{array}{l}\text { Field and catch- } \\
\text { ment / ASTER, } \\
\text { Landsat, MODIS }\end{array}$ & Iowa, USA & Corn and soybeans & $\begin{array}{l}\text { Tendency for over prediction with SEBS } \\
\text { but good correlation to field measured } \\
\text { values: } r^{2}=0.71 \text { for ASTER and } r^{2}=0.74 \\
\text { for Landsat. }\end{array}$ & $\begin{array}{l}\text { McCabe and } \\
\text { Wood (2006) }\end{array}$ \\
\hline $\begin{array}{l}\text { Regional / ASTER, } \\
\text { MODIS }\end{array}$ & Costa Rica & Wetlands & $\begin{array}{l}\text { Within } 10 \% \text { of } E T \text { (from water level deter- } \\
\text { mination of storage) }\end{array}$ & Alvarez (2007) \\
\hline Regional / MODIS & $\begin{array}{l}\text { Red-Arkansas } \\
\text { River Basin, USA }\end{array}$ & $\begin{array}{l}\text { Varied: forest, wooded } \\
\text { grassland, cropland, } \\
\text { open shrubland }\end{array}$ & $\begin{array}{l}\text { SEBS retrieved } E T \text { values are higher than } \\
\text { Variable Infiltration Capacity based } \\
\text { predictions }\end{array}$ & Pan et al. (2008) \\
\hline Regional / MODIS & Northwest China & $\begin{array}{l}\text { Varied: predominantly } \\
\text { barren or sparsely veg- } \\
\text { etated land }\end{array}$ & $\#$ & Xin (2007) \\
\hline Regional / MODIS & Arizona, USA & $\#$ & $\begin{array}{l}\text { For soil moisture anomalies from } \\
\text { AMSR-E there is considerable agree- } \\
\text { ment with available sensible heat flux } \\
\text { predictions }\end{array}$ & $\begin{array}{l}\text { McCabe et al. } \\
(2008)\end{array}$ \\
\hline $\begin{array}{l}\text { Field scale / } \\
\text { ASTER }\end{array}$ & $\begin{array}{l}\text { Central } \\
\text { Netherlands }\end{array}$ & Forests & $\begin{array}{l}\text { Severe overestimation of latent heat flux } \\
\text { and underestimation of sensible heat flux } \\
\text { in forested areas. }\end{array}$ & Badola (2009) \\
\hline $\begin{array}{l}\text { Local: sub-catch- } \\
\text { ment / MODIS }\end{array}$ & Salamanca, Spain & $\begin{array}{l}\text { Dryland agriculture, } \\
\text { some irrigated crops }\end{array}$ & $\begin{array}{l}r^{2} \text { of } 0.86 \text { and } 0.91 \text { when compared with } \\
\text { complimentary approach }\end{array}$ & Gebreyesus (2009) \\
\hline Regional / MODIS & $\begin{array}{l}\text { Yellow River Delta, } \\
\text { China }\end{array}$ & Wetland & $\begin{array}{l}\text { Eta reported to be acceptable when com- } \\
\text { pared with } E T_{0} \\
\text { RMSE for Suaeda heteroptera }=0.88 \mathrm{~mm} \\
\text { 'reed swamp' }=1.3 \mathrm{~mm}\end{array}$ & Jia et al. (2003) \\
\hline Field / ASTER & Barrax, Spain & $\begin{array}{l}\text { Forest nursery, wheat } \\
\text { stubble, vineyard, sun- } \\
\text { flower, corn }\end{array}$ & $\begin{array}{l}\text { Standard deviations of SEBS estimated } \\
\mathrm{H} \text { similar to field measured values. SEBS } \\
\text { estimated } \mathrm{H} \text { good when the footprint of } \\
\text { the measurements covers only one land } \\
\text { cover type. }\end{array}$ & $\begin{array}{l}\text { Van der Kwast et } \\
\text { al. (2009) }\end{array}$ \\
\hline $\begin{array}{l}\text { Catchment / } \\
\text { MODIS }\end{array}$ & Zimbabwe & Urban, grasslands & $\begin{array}{l}\text { Urban: mean absolute error of } 0.5 \mathrm{~mm} \cdot \mathrm{d}^{-1} \\
\text { Grasslands: mean absolute error of } 2.6 \\
\mathrm{~mm} \cdot \mathrm{d}^{-1}\end{array}$ & $\begin{array}{l}\text { Rwasoka et al. } \\
(2011)\end{array}$ \\
\hline
\end{tabular}

\# Not reported 
resolution of readily available satellite imagery at a daily time scale; the sensitivity of the model to various input parameters which are difficult to accurately deduce at appropriate spatial scale; and the assumptions made at micrometeorological level in the model make the accurate and realistic estimation of energy fluxes improbable at both field and catchment scale.

\section{CONCLUSIONS AND RECOMMENDATIONS}

The use of remote sensing-based methods for estimating ET has gained momentum in the past 5 years and holds great potential for monitoring water use and ET across various spatial and temporal scales, and for being integrated into operational water resource management systems in South Africa. This study showed that the SEBAL model has been widely and successfully applied in a historical context in South Africa for water use efficiency studies (Klaasse et al., 2008). The success of these historic studies has evolved such that the SEBAL model is now being implemented operationally for water use monitoring, water use efficiency and planning purposes for various crops (Jarmain et al., 2011b, 2012, 2013) and at catchment scale (WE Consult, 2011). However, the SEBAL model is protected by intellectual property law and is therefore not available for unaffiliated researchers to use, so alternative methods should be investigated.

The SEBS model is available as part of the open-source freeware ILWIS and can therefore be used by practitioners with remote-sensing knowledge who may not necessarily have the micrometeorological expertise to develop a model themselves to estimate ET. Despite adaptations to the methodology to address model sensitivities (Gibson et al., 2011b), the results of South African research using the SEBS model did not yield accurate daily evaporation results at MODIS resolution. However, at Landsat resolution, promising results have been obtained (Jarmain et al., 2009). It is therefore concluded that in complex, semi-arid environments, at coarse (MODIS) resolution, it is not possible to adequately describe the remote sensing-derived input parameters at the correct level of accuracy and spatial resolution required for the accurate estimation of the sensible heat flux. However, at Landsat resolution it may be possible to retrieve more accurate estimates. Because of the discrepancy in the accuracy of results by Gibson et al. (2009, 2011b) and Jarmain et al. (2009) - which may be partially ascribed to the differing resolutions of satellite sensors used - it is recommended that any further research using the SEBS model in South Africa should be limited to agricultural areas where accurate vegetation parameters can be obtained, where high resolution imagery with low sensor zenith angles is available and where canopy cover is complete.

Given the success of the SEBAL model in terms of accuracy and the speed with which the data product has been operationalised, it is recommended that this thrust be maintained, particularly for irrigated crops in water use efficiency and water use monitoring applications. In spite of the limitations which have been uncovered pertaining to the SEBS model, the potential uses of this approach should not be overlooked. Since the SEBS model is available freely in a variety of packages, its application for teaching and training purposes should be expanded.

Finally, as a matter of priority, the validation of the recently released MODIS evapotranspiration data product, MOD16, developed by $\mathrm{Mu}$ et al. (2011), is required in the South African environment. It is anticipated that MOD16 will generate considerable interest in South Africa for coarse-resolution ET estimates. It is important that the accuracy of the product is ascertained across South African conditions in order to determine the potential constraints and uncertainties of the ET estimates.

\section{REFERENCES}

ALLEN RG, TASUMI M and TREZZA R (2007) Satellite-based energy balance for mapping evapotranspiration with internalized calibration (METRIC)-Model. J. Irrig. Drain. 133 395-406.

ALVAREZ JAG (2007) Effects of land cover changes on the water balance of the Palo Verde Wetland, Costa Rica. MSc thesis, International Institute for Geo-information Science and Earth Observation, The Netherlands.

BADOLA A (2009) Validation of Surface Energy Balance System (SEBS) over forest land cover and sensitivity analysis of the model. MSc thesis, International Institute for Geo-information Science and Earth Observation, The Netherlands.

GEBREYESUS MG (2009) Validation of RS approaches to model surface characteristics in hydrology: a case study in Guareña Aquifer, Salamanca, Spain. MSc thesis, International Institute for Geoinformation Science and Earth Observation, The Netherlands.

GIBSON LA, MÜNCH Z, ENGELBRECHT J, PETERSEN N and CONRAD JE (2009) Remote sensing as a tool towards resource assessment and determination of the legal compliance of surface and groundwater use. WRC Report No. 1690/1/09. Water Research Commission, Pretoria.

GIBSON LA, MÜNCH Z and ENGELBRECHT J (2011a) Particular uncertainties encountered in using a pre-packaged SEBS model to derive evapotranspiration in a heterogeneous study area in South Africa. Hydrol. Earth Syst. Sci. 15 295-310.

GIBSON LA, MÜNCH Z, CARSTENS M and CONRAD JE (2011b) Remote sensing evapotranspiration (SEBS) evaluation using water balance. WRC Report No. KV 272/11. Water Research Commission, Pretoria.

HAILEGIORGIS WS (2006) Remote sensing analysis of summer time evapotranspiration using SEBS algorithm: A case study in Regge and Dinklel, The Netherlands. MSc thesis, International Institute for Geo-information Science and Earth Observation, The Netherlands.

HELLEGERS PJGJ, JANSEN HC and BASTIAANSSEN WGM (2011) An interactive water indicator assessment tool to support land use planning. Irrig. Drain. 61 (2) 143-154. DOI: 10.1002/ird.641.

JARMAIN C, MENGITSU M, JEWITT GPW, KONGO V and BASTIAANSSEN W (2009) A methodology for near-real time spatial estimation of evaporation. WRC Report No. 1751/1/09. Water Research Commission, Pretoria.

JARMAIN C and MEIJNINGER WL (2012) Assessing the impact of Invasive Alien Plants on South African water resources using remote sensing techniques. In: Neale CMU and Cosh MH (eds.) Proceedings of a Symposium organized by the International Commission on Remote sensing of IAHS, held at Jackson Hole, Wyoming, USA, 27-30 September 2010. IAHS Publication No. 352. IAHS Press, Oxfordshire. 388-392.

JARMAIN C, KLAASSE A, BASSON FC, MEIJNINGER W, WILMINK S and BASTIAANSSEN W ( 2011a) Developing an operational remote sensing system for monitoring of efficient crop water and nitrogen use of grapes, Western Cape Province. Final report to the Western Cape Provincial Department of Agriculture, July 2011. 85 pp.

JARMAIN C, SINGELS A, OBANDO E, PARASKEVOPOULOS A and MTHEMBU I (2011b) Water use efficiency of irrigated agricultural crops determined with satellite imagery. WRC Project No. K5/2079//4, Progress Report, December 2011. Water Research Commission, Pretoria.

JARMAIN C, SINGELS A, OBANDO E, PARASKEVOPOULOS A, OLIVIER F, MUNCH Z, VAN DER MERWE B, WALKER S, VAN DER LAAN M, MESSEHAZION M, SAVAGE M, PRETORIUS C, ANNANDALE J and EVERSON C (2013) Water use efficiency of irrigated agricultural crops determined with satellite imagery. WRC Project No. K5/2079//4, Deliverable 6, Water Use Efficiency Report 2012/13, 15 January 2013. Water Research Commission, Pretoria. 
JARMAIN C and KLAASSE A (2012) Fruitlook: An operational service to improved crop water and nitrogen management in grapes and other deciduous fruit trees using satellite technology for the season of 2011-12. Progress Report, Western Cape Provincial Department of Agriculture.

JARMAIN C and MENGISTU MG (2011) Validating energy fluxes estimated using the surface energy balance system (SEBS) model for a small catchment. WRC Report No. KV290/11, Water Research Commission, Pretoria. ISBN 978-1-4312-0184-6.

JHA MK and CHOWDARY VM (2006) Challenges of using remote sensing and GIS in developing nations. Hydrogeol. J. 15 197-200.

JIA L, SU Z, VAN DEN HURK B, MENENTI M, MOENE HAR, BASELGA YRISARRY JJ, IBANEZ M and CUESTA A (2003) Estimation of sensible heat flux using the Surface Energy Balance System (SEBS) and ATSR measurements. Phys. Chem. Earth $\mathbf{2 8}$ 75-88.

KLAASSE A, BASTIAANSSEN W, JARMAIN C and ROUX A (2008) Water use efficiency of table and wine grapes in Western Cape, South Africa. WaterWatch report, Wageningen, The Netherlands. $68 \mathrm{pp}$.

KLAASSE A, JARMAIN C, ROUX A, BECU O and GINATI A (2011) GrapeLook: space based services to improve water use efficiency of vineyards in South Africa. Proc. $62^{\text {nd }}$ International Astronautical Congress, 3-7 October 2011, Cape Town.

KONGO VM and JEWITT GPW (2006) Preliminary investigation of catchment hydrology in response to agricultural water use innovations: A case study of the Potshini catchment- South Africa. Phys. Chem. Earth 31 976-987.

LIN W (2006) Satellite based regional scale evapotranspiration in the Hebei Plain, Northeastern China, MSc thesis, International Institute for Geo-information Science and Earth Observation, The Netherlands.

LIN W, VAN DE VELDE R and SU Z (2008) Satellite based regionalscale evapotranspiration in the Hebei Plain, Northeastern China. Proc. Dragon 1 Programme Final Results 2004-2007, 21-25 April 2008, Beijing, China.

McCABE MF and WOOD EF (2006) Scale influences on the remote estimation of evapotranspiration using multiple satellite sensors. Remote Sens. Environ. 105 271-285.

McCABE MF, WOOD EF, WÓJCIK R, PAN M, SHEFFIELD J, GAO $\mathrm{H}$ and SU H (2008) Hydrological consistency using multi-sensor remote sensing data for water and energy cycle studies. Remote Sens. Environ. 112 430-444.

MELESSE AM, OBERG J, NANGIA V, BEERI O and BAUMGARTNER D (2006) Spatiotemporal dynamics of evapotranspiration at the Glacial Ridge prairie restoration in northwestern Minnesota. Hydrol. Process. 20 1451-1464.

MU QZ, HEINSCH FA, ZHAO M and RUNNING SW (2007) Development of a global evapotranspiration algorithm based on
MODIS and global meteorology data. Remote Sens. Environ. 111 519-536.

MU QZ, ZHAO MS and RUNNING SW (2011) Improvements to a MODIS global terrestrial evapotranspiration algorithm. Remote Sens. Environ. 115 1781-1800.

PALMER AR and WEIDEMAN CI (2011) Exploring trends in evapotranspiration in the KNP: towards a water use efficiency model for rangeland production in semi-arid savannas. Proc. IXth International Rangeland Congress, 2-8 April 2011, Rosario, Argentina.

PAN M, WOOD EF, WÓJCIK R and McCABE MF (2008) Estimation of regional terrestrial water cycle using multi-sensor remote sensing observations and data assimilation. Remote Sens. Environ. 112 1282-1294.

RWASOKA DT, GUMINDOGA W and GWENZI J (2011) Estimation of actual evapotranspiration using the Surface Energy Balance System (SEBS) algorthim in the Upper Manyame catchment in Zimbabwe. Phys. Chem. Earth. 36 736-746.

SAVAGE MJ, EVERSON CS, ODHIAMBO GO, MEGISTU MJ and JARMAIN C (2004) Theory and practice of evaporation measurement, with special focus on SLS as an operational tool for the estimation of spatially-averaged evaporation. WRC Report No. 1335/1/04. Water Research Commission, Pretoria.

SU Z (2002) The surface energy balance system (SEBS) for estimation of turbulent heat fluxes. Hydrol. Earth Syst. Sci. 6 85-99.

SU Z and ROERINK GJ (eds.) (2004) Drought Risk Reduction. Alterrarapport 1135, Wageningen, The Netherlands.

SU H, McCABE MF and WOOD EF (2005) Modeling Evapotranspiration during SMACEX: Comparing two approaches for local- and regional-scale prediction. J. Hydrometeorol. 6 910-922.

TIMMERMANS WJ, VAN DER KWAST J, GIESKE ASM, SU Z, OLIOSO A, JIA L and ELBERS J (2005) Intercomparison of energy flux models using ASTER imagery at the SPARC 2004 site, Barrax, Spain. Proceedings of the ESA WPP-250: SPARC final workshop, 4-5 July 2005, Enschede, The Netherlands.

VAN DER KWAST J, TIMMERMANS W, GIESKE A, SU Z, OLIOSO A, JIA L, ELBERS J, KARSSENBERG D and DE JONG S (2009) Evaluation of the Surface Energy Balance System (SEBS) applied to ASTER imagery with flux-measurements at the SPARC 2004 site (Barrax, Spain). Hydrol. Earth Syst. Sci. 13 1337-1347.

VERSTRAETEN WW, VEROUSTRAETE F and FEYEN J (2008) Assessment of evapotranspiration and soil moisture content across different scales of observation. Sensors 8 70-117.

WE CONSULT (2011) Operational Monitoring Product for Planning and Water Allocation in the International Incomati Basin (WATPLAN). Stakeholder analysis report. We Consult, Maputo. 53 pp.

XIN S (2007) Regional evaporation over the arid inland Heihe River Basin in Northwest China. MSc thesis, International Institute for Geo-Information Science and Earth Observation, The Netherlands. 
http://dx.doi.org/10.4314/wsa.v39i4.5 Available on website http://www.wrc.org.za

ISSN 0378-4738 (Print) $=$ Water SA Vol. 39 No. 4 July 2013 ISSN 1816-7950 (On-line) $=$ Water SA Vol. 39 No. 4 July 2013 